\title{
Carbon Stock Evaluation and Potential Carbon Market Value Determination of Ashaavieen Nature Reserve, Msallata, Libya
}

\author{
Hosam Ali Aldhawi Ashokri \\ Biology Department, Faculty of Science, El-Mergib University, Al-Khums, Libya.
}

Received: 25 January 2021/ Accepted: 29 April 2021

Doi: https://doi.org/10.54172/mjsc.v36i2.34

\begin{abstract}
This study targets to assign the total carbon stock of Ashaavieen Nature Reserve, Msallata, Libya, assisting its potential carbon market value based on different global market sources. Northern and Southern sites were adopted representing the dominant tree species; (Pinus halepensis, Ziziphus lotus, and Ceratonia siliqua). The samples were conducted across the summer and winter of 2020 to get an annual average. These samples were classified into leaves, stems, bark (aboveground), and roots (belowground). The soil samples were collected at $0-10 \mathrm{~cm}, 10-20 \mathrm{~cm}$, and 20-30 cm depth. Organic carbon content was assessed based on the Loss on Ignition method (LOI). The results have shown that the bark has recorded the highest carbon content rate, followed by the stem, leaf, and root. Also, the carbon in soil samples has a direct relationship with depth in the order of $(0-10 \mathrm{~cm})>(10-20 \mathrm{~cm})>(20-30 \mathrm{~cm})$. Total carbon stock was $870.47(\mathrm{t} / \mathrm{ha} / \mathrm{yr})$ and $1858.21(\mathrm{t} / \mathrm{ha} / \mathrm{yr})$ in Northern and Southern sites. Total tree coverage of the study area was estimated at 91.26 hectares, while the potential carbon market value ranged from 0.72 t0 32.09 million USD.
\end{abstract}

Keywords: Ashaavieen Nature Reserve, Carbon Stock, Carbon Market Value, Loss on Ignition.

\section{INTRODUCTION}

Forest ecosystems could play a vital role in global carbon regulation and climatic change mitigation ( $\mathrm{Li}$ et al., 2019). But, the rapid growth in social and economic levels frighteningly harms those ecosystems as it shrinks at alarming rates. Forestlands in the Arab Region cover nearly $6 \%$ of the total forest coverage worldwide. About 217 thousand ha. Libya containing 6 million tons of carbon in forest living biomass alone (El-Baha et al., 2010).

(FAO \& UNEP, 2020) has emphasized that approximately 420 million hectares of forestlands were lost since 1990 due to conversion to other land uses. Mathematically, if this repulsive stress continues, all forest ecosystems would disappear in 290 years.
The significance of carbon stock evaluation comes due to the direct relationship between forest regression and carbon stock retraction. (Van der Werf et al., 2009) have reported that deforestation contributes approximately onefifth of the yearly GHGs emissions.

Ashokri (2020) find out that Pinus halepensis is the most dominant species with an Importance Value Index (IVI) of $66.64 \%$, followed by Ziziphus lotus and Ceratonia siliqua about $11.78 \%$ and $11.77 \%$, respectively. The highest biomass value was Pinus halepensis at $7888.27 \mathrm{t} \mathrm{ha}^{-1}$.

Aboveground, belowground biomass, and soil carbon are the most significant contributors to the total ecosystem carbon. The forest soil participates in more than two-thirds of the total carbon stored in the forest ecosystem due to a strong relationship between plant

*Corresponding Author: Hosam Ali Aldhawi Ashokri haalshukri@elmergib.edu.ly, Biology Department, Faculty of Science, El-Mergib University, Al-Khums, Libya. 
biomass and terrestrial carbon (Ahmed, 2018).

The global carbon market establishment is vital as an effective tool for global climatic change mitigating and testing the efficiency of climate protection. It is also to confirm that the significance of forest ecosystems is not limited by the goods they provide. Based on (Lin, 2020), the traded volume of global carbon markets has reached 8.7 billion tons worth about 260 billion USD. This study aims to determine the total carbon stock and its potential carbon market value of the study area.

\section{MATERIALS AND METHODS}

This study was carried out at the Nature Reserve of Ashaavieen, Msallata, Libya $\left(32.589128^{\circ} \mathrm{N}, 13.865004^{\circ} \mathrm{E}\right)$ fig (1), which is about $90 \mathrm{~km}$ far from the capital city. The total area of Ashaavieen Reserve is about 496 ha (Ashokri, 2020). Two sites (N and S) were chosen based on the presence of the selected species. The samples were collected through summer and winter.

These samples were taken out from the living parts of four trees. These parts are the leaf, stem, bark, and root for each species (Pinus halepensis, Ziziphus lotus, and Ceratonia sili$q u a)$. The leaf samples were taken by the leafcutter (Corona TP 6881).

The stem samples were obtained via drilling until the stem center, while the bark samples were stripped with a keen knife at the chest height $(1.5 \mathrm{~m})$. These samples were dried at 70 ${ }^{\circ} \mathrm{C}$ to ensure stable readings of weight. Then the samples were grinded and placed into plastic containers to be transferred to the Muffle Furnace. Plant biomass total carbon stock was estimated using the following equation:

Organic Carbon Content $\left(t h a^{-1}\right)=$ mean organic carbon content of the highest two living parts $(\%) *$ total Biomass $\left(t \mathrm{ha}^{-1}\right)$.

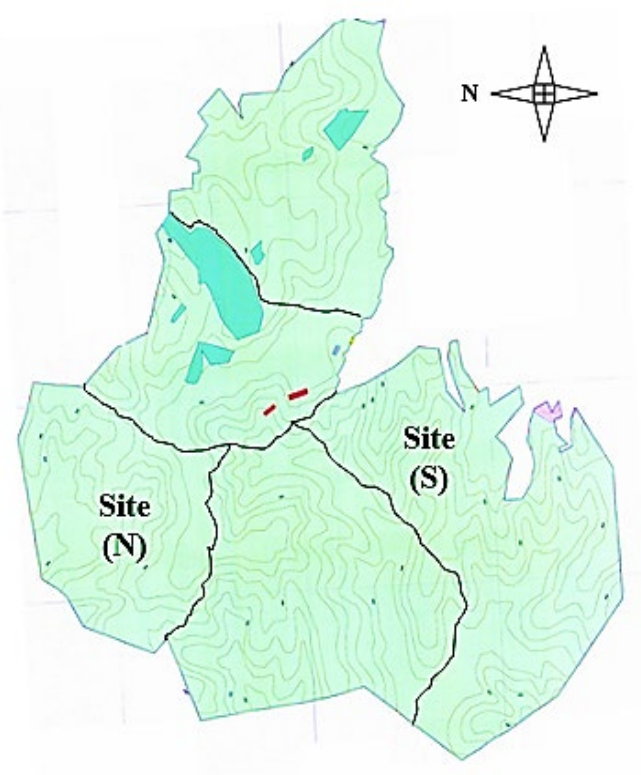

Figure: (1) Study Area (Alhusein et al., 2017).

The soil samples were collected using $5 \mathrm{~cm}$ in diameter PVC pipe from three depths (0-10 $\mathrm{cm}),(10-20 \mathrm{~cm})$, and $(20-30 \mathrm{~cm})$ as scarce differences after the depth of $30 \mathrm{~cm}$ (Balesdent et al., 2018). The soil samples were dried and sieved using a $2 \mathrm{~mm}$ sieve. These samples were then kept in plastic containers before being placed into the Muffle Furnace. Soil Carbon content was estimated using the following formula:

Soil Carbon $\left(\mathrm{Mg} \mathrm{ha}^{-1}\right)=$ bulk density $\left(\mathrm{g} \mathrm{cm}^{-}\right.$ $\left.{ }^{3}\right) *$ soil depth interval $(\mathrm{cm}) * \mathrm{C} \%$.

According to (Perera \& Amarasinghe, 2013), the total carbon was calculated by adding up the mean carbon content of the living parts and the total soil carbon of the chosen year ( $\mathrm{t}$ ha $\mathrm{C}$ $\left.\mathrm{yr}^{-1}\right)$. The total carbon stock for the whole study area was estimated based on the following equation:

Total Ecosystem Carbon Stock of a targeted area $(\mathrm{Mg})=$ total carbon $\left(\mathrm{Mg} \mathrm{ha}^{-1}\right) *$ Area (ha).

Total tree coverage of the study area was estimated using ArcGIS 10.8 
The total carbon stock of the ecosystem was converted into $\mathrm{CO}_{2}$ equivalents (as $\mathrm{CO}_{2}$ is the most common GHG in the atmosphere), and the following formula was utilized:

Total Potential $\mathrm{CO}_{2}$ Emissions per hectare $\left(\mathrm{CO}_{2}\right.$ e $)=$ total carbon stock of the ecosystem * 3.67 (conversion Factor) based on (Kauffman \& Donato, 2012).

The potential carbon market value was calculated by multiplying the total ecosystem carbon stock with carbon unit price (based on the carbon unit price of the market used) as follows:

Potential Carbon Market Value (USD) = total ecosystem carbon stock $(\mathrm{Mg}) *$ carbon unit price (USD)

\section{RESULTS \& DISSCUSSION}

The results indicated that the bark has the highest organic carbon content within living parts, around $61.12 \% \pm 2.5$ at the Northern site and about $66.00 \% \pm 4.01$ at the Southern site. In comparison, the roots have the lowest at $42.77 \% \pm 1.12$ and $45.30 \% \pm 1.82$ at Northern and Southern sites, respectively. The carbon content was high in the bark, followed by the stem, leaf, and root, respectively (Figure 2); this agreed with (Madeira et al., 2002).
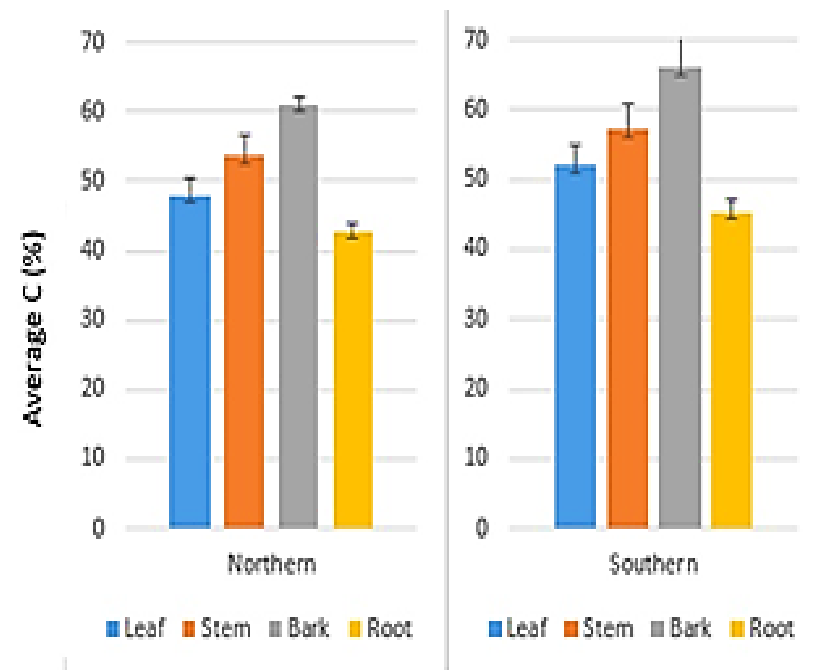

Figure: (2). Carbon Distribution in Living Parts.
Southern site than in the Northern Site at 322.50 and 190.42 (t/ha/yr). This could be a result of the positive relationship between biomass and carbon stock of an ecosystem (Wassihun et al., 2019).

The results also show that approximately $72 \%$ and $79 \%$ of the total carbon stock was stored in the soil. It is estimated at roughly 680.07 in $\mathrm{N}$ and 1535.71 (t/ha/yr) in S (Table: 1). This result is similar to (Edmondson et al., 2015) that indicates soil contributes around $75 \%$ of the total ecosystem carbon stock.

The contain of carbon storage in soil was high in upland soil $(0-10 \mathrm{~cm})$, then depth $(10-20$ $\mathrm{cm})$ and depth $(20-30 \mathrm{~cm})$ as a consequence of the carbon content goes in parallel with depth (Lawrence et al., 2015).

The results illustrate that the assessment of carbon distribution over seasons was higher in summer than winter in both sites as primary productivity is related to temperature levels (Ontl \& Schulte, 2012).

Table: (1). Ecosystem Carbon Stock in both Study Sites.

\begin{tabular}{lcc}
\hline \hline \multicolumn{1}{c}{ Carbon Stocks } & $\begin{array}{c}\text { Northern Site } \\
(\mathrm{t} / \mathrm{ha} / \mathrm{yr})\end{array}$ & $\begin{array}{c}\text { Southern Site } \\
(\mathrm{t} / \mathrm{ha} / \mathrm{yr})\end{array}$ \\
\hline $\begin{array}{l}\text { Carbon Stock in Liv- } \\
\text { ing Parts (ABG \& }\end{array}$ & 190.42 & 322.50 \\
$\begin{array}{l}\text { BG) } \\
\text { Soil Carbon Stock }\end{array}$ & 680.07 & 1535.71 \\
Total & 870.49 & 1858.21 \\
\hline \hline
\end{tabular}

The potential carbon market value is ranged from 0.72 to 23.09 million USD (Table 2) based on the estimation of the total tree coverage, which was around 91.26 ha.

Total biomass carbon stock was higher in the

Table: (2). Price of Carbon Stocks Based on Some Global Markets.

(C) 2021 The Author(s). This open access article is distributed under a CC BY-NC 4.0 license. ISSN: online 2617-2186 print 2617-2178 


\begin{tabular}{|c|c|c|c|}
\hline $\begin{array}{l}\text { Ecosystem Carbon Stock } \\
\left(\mathrm{T} \mathrm{C} \mathrm{yr}{ }^{-1}\right)\end{array}$ & Voluntary Market & GHGs Initiative & EU ETS \\
\hline $\begin{array}{c}(\text { N Site) } 870.49 * 91.26 \text { ha }= \\
(79440.91)\end{array}$ & $\begin{array}{c}79440.41 * 6 \mathrm{USD}= \\
(746642.46)\end{array}$ & $\begin{array}{c}79440.41 * 9.69 \text { USD }= \\
(769777.57)\end{array}$ & $\begin{array}{c}79440.41 * 191.80 \mathrm{USD}= \\
15.23 \mathrm{mil})\end{array}$ \\
\hline $\begin{array}{c}(\mathrm{S} \text { Site }) \\
1858.21 * 91.26 \mathrm{ha}= \\
(169580.24)\end{array}$ & $\begin{array}{c}169580.24 * 6 \mathrm{USD} \\
\mathrm{mil})\end{array}$ & $\begin{array}{c}169580.24 * 9.69 \mathrm{USD}= \\
(1.68 \mathrm{mil})\end{array}$ & $\begin{array}{c}169850.24 * 191.80 \text { USD }= \\
(32.57 \mathrm{mil})\end{array}$ \\
\hline $\begin{array}{c}\text { (Average) } \\
1319.35 * 91.26 \text { ha }= \\
(120403.88)\end{array}$ & $\begin{array}{c}120403.88 * 6 \text { USD }= \\
(722423.28)\end{array}$ & $\begin{array}{c}120403.88 * 9.69 \text { USD }= \\
(1.16 \mathrm{mil})\end{array}$ & $\begin{array}{l}120403.88 * 191.80 \mathrm{USD}= \\
(23.09 \mathrm{mil}\end{array}$ \\
\hline
\end{tabular}

\section{CONCLUSION}

The study concludes that organic carbon content in three parts was high in the bark, then stem, leaf and root. The soil carbon constitutes about three-quarters of the total ecosystem carbon stock and the highest amount in the third layer $(20-30 \mathrm{~cm})$. The carbon storage amount over seasons was higher in summer than in winter. The potential carbon market value of the study area was in the range of $0.72-32.09$ million USD.

\section{ACKNOWLEDGEMENT}

The author would like to express his deep gratitude to the Biology Department, Faculty of Science, El-Mergib University, and Ashaavieen Nature Reserve staff for their assistance.

\section{REFERENCES}

Ahmed, I. U. (2018). Forest Soil C: Stock and Stability under Global Change. New Perspectives in Forest Science, 37.

Alhusein, M. E., Salem, A. M., \& Mustafa, O. A. (2017). Evaluation of Environmental Situation on the Vegetation and Strategy of Its Developing in a Reserve of Msallata at Libya.

Ashokri, H.A. (2020). Diversity and Biomass Estimation of Tropical and SubTropical Trees on Ashaavieen Nature Reserve, Msallata, Libya. Al-Bayan Scientific Journal, 202-207.
Balesdent, J., Basile-Doelsch, I., Chadoeuf, J., Cornu, S., Derrien, D., Fekiacova, Z., \& Hatté, C. (2018). Atmosphere-soil carbon transfer as a function of soil depth. Nature, 559(7715), 599-602.

Edmondson, J. L., Stott, I., Potter, J., LopezCapel, E., Manning, D. A., Gaston, K. J., \& Leake, J. R. (2015). Black carbon contribution to organic carbon stocks in urban soil. Environmental science \& technology, 49(14), 8339-8346.

El-Baha, A., Omran, T., Regato, P., Saket, M., Braatz, S., Achouri, M., Tranberg, J., \& Rose, S. (2010). Forests and climate change in the Near East region.

FAO, U. (2020). The state of the world's forests 2020: forests, biodiversity, and people: Rome

Kauffman, J. B., \& Donato, D. C. (2012). Protocols for the measurement, monitoring and reporting of structure, biomass, and carbon stocks in mangrove forests. Citeseer.

Lawrence, C. R., Harden, J. W., Xu, X., Schulz, M. S., \& Trumbore, S. E. (2015). Long-term controls on soil organic carbon with depth and time: A case study from the Cowlitz River Chronosequence, WA USA. Geoderma, 247, 73-87.

Li, Y., Bao, W., Bongers, F., Chen, B., Chen, G., Guo, K., Jiang, M., Lai, J., Lin, D., \& Liu, C. (2019). Drivers of tree carbon 
storage in subtropical forests. Science of the Total Environment, 654, 684-693.

Lin, W. (2020). Air transport carbon reduction optimization based on low carbon emissions. IOP Conference Series: Earth and Environmental Science,

Madeira, M., Fabiao, A., Pereira, J., Araújo, M., \& Ribeiro, C. (2002). Changes in carbon stocks in Eucalyptus globulus Labill. plantations induced by different water and nutrient availability. Forest Ecology and Management, 171(1-2), 75-85.

Ontl, T. A., \& Schulte, L. A. (2012). Soil carbon storage. Nature Education Knowledge, $3(10)$.

Perera, K., \& Amarasinghe, M. (2013). Carbon Partitioning and Allometric Relationships between Stem Diameter and Total Organic Carbon (TOC) in Plant Components of Bruguiera gymnorrhiza (L.) Lamk. and Lumnitzera racemosa Willd. in a Microtidal Basin Estuary in Sri Lanka. International Journal of Marine Science, 3.

Van der Werf, G. R., Morton, D. C., DeFries, R. S., Olivier, J. G., Kasibhatla, P. S., Jackson, R. B., Collatz, G. J., \& Randerson, J. T. (2009). CO 2 emissions from forest loss. Nature geoscience, 2(11), 737-738.

Wassihun, A. N., Hussin, Y. A., Van Leeuwen, L., \& Latif, Z. A. (2019). Effect of forest stand density on the estimation of above ground biomass/carbon stock using airborne and terrestrial LIDAR derived tree parameters in tropical rain forest, Malaysia. Environmental Systems Research, 8(1), 1-15. 


\title{
تقدير مخزون الكريون وتحديد قيمته السوقية لمحمية الشعافيين الطبيعية، مسلاتة، ليبيا
}

\author{
حسام علي الضاوي الثكري \\ قسم الأحياء، كلية العلوم، جامعة المرقب، الخس، ليييا \\ تاريخ الاستلام: 25 يناير 2021 / تاريخ القبول: 28 أبريل 2021 \\ https://doi.org/10.54172/mjsc.v36i2.34:Doi
}

المستخلص: تهدف الدراسة إلى تحديد إجمالي مخزون الكربون في محمية الثعافيين الطبيعية، مسلاتة، ليييا، وتحديد قيمتها

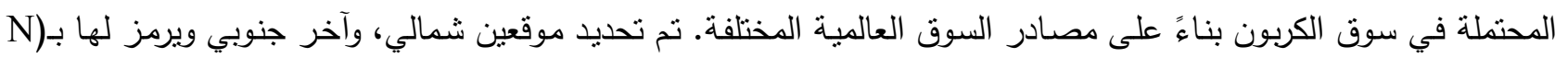

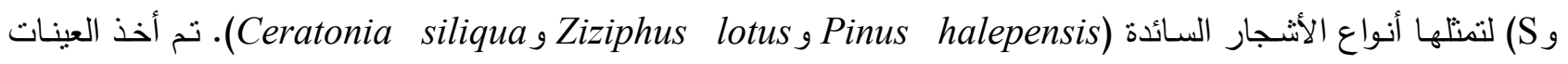

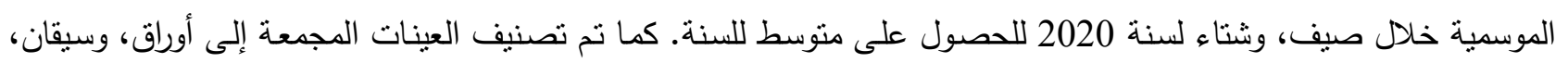

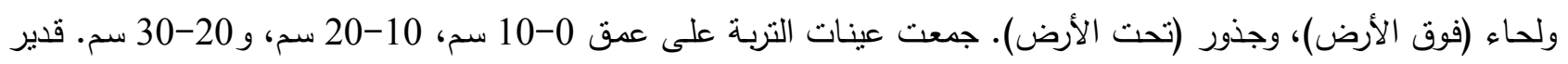

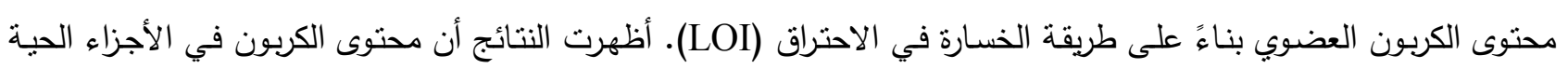

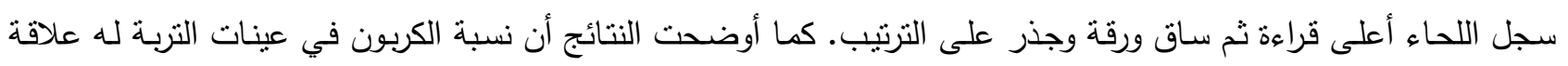

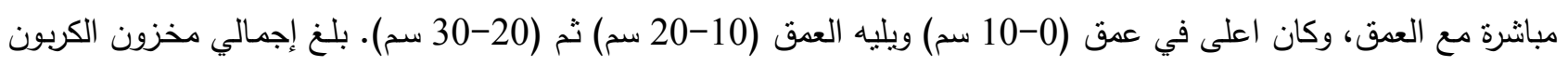

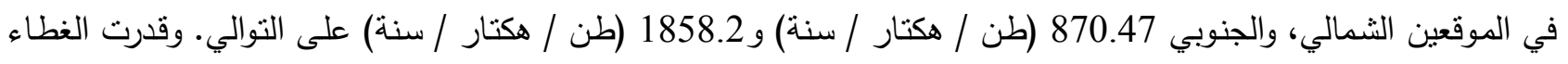

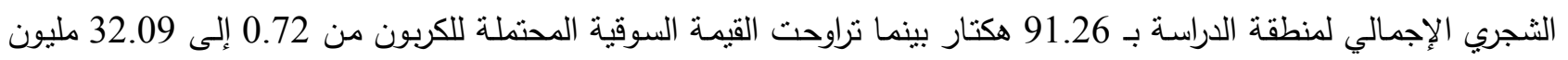
دولار أمريكي. الكلمات المفتاحية: محمية الثعافيين الطبيعية، مخزون الكربون، القيمة السوقية للكربون، الخسارة في الاحتراق. 